\title{
IMPACT OF CLIMATE CHANGE ON THE INDIAN ECONOMY: EVIDENCE FROM FOODGRAIN YIELDS
}

SHREEKANT GUPTA

Email: sgupta@econdse.org

Delhi School of Economics

University of Delhi

\&

LKY School of Public Policy (NUS)

PARTHA SEN

Email: partha@econdse.org

South Asian University

SUCHITA SRINIVASAN

Email: suchita.srinivasan18@gmail.com

American Express

Working Paper No. 218 


\title{
Impact of Climate Change on the Indian Economy: Evidence from Foodgrain Yields
}

\author{
Shreekant Gupta, Partha Sen and Suchita Srinivasan ${ }^{* \#}$
}

\begin{abstract}
This paper estimates the impact of climate change on foodgrain yields in India, namely rice and millets. We estimate a crop-specific agricultural production function with exogenous climate variables, namely, precipitation and temperature and control for key inputs such as irrigation, fertilizer and labour. Our analysis is at the district level using a panel dataset for physical yield (output per hectare - gross cropped area) for the period 1966-99. Thus, we eschew crop simulation approaches that rely on experimental data. We do not also estimate reduced form relationships between economic variables such as profits or the monetary value of yield and weather measures. Consistent with other studies at the district and state level we find significant impacts of climate change (temperature and precipitation) on Indian agriculture. The implication of our results for inter-state disparities and corrective measures is elaborated.
\end{abstract}

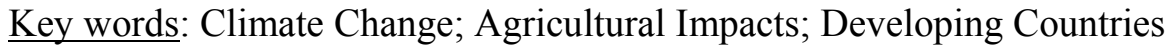

JEL Classification: O13; Q54; R11

\footnotetext{
${ }^{*}$ Authors are in alphabetic order. They are, respectively, with Delhi School of Economics and LKY School of Public Policy, South Asian University and American Express. Corresponding author: Gupta (sgupta@econdse.org, sgupta@nus.edu.sg)

\# We thank Centre for Development Economics, Delhi School of Economics for financial support through UK Department of International Development (DfID) Purchase Order No. 40048622. We alone are responsible for the findings and conclusions.
} 


\section{Introduction}

Meteorological data compiled over the past century suggest the earth is warming. In keeping with this, for India as a whole mean annual temperature shows a significant warming trend of 0.51 degrees Celsius per 100 years during the period 1901-2007 (Kothawale et al., 2010). Similarly, global projections of temperature and for precipitation augur a warmer and wetter world, on average. Simulations with regional climate models project similar trends for both variables for India - by 2030s annual mean temperatures and summer monsoon rainfall are both expected to increase on average (GoI 2010). But for a country of sub-continental proportions there are, as expected, significant regional variations in past and future trends. Both these facts have significant implications for the Indian economy in terms of the impact of climate change and also its regional incidence.

This is particularly true for the agricultural sector where climate is a direct input into production. While the salience of this sector in India has declined over the years, it still remains important in the socio-economic fabric of the country. Though agriculture alone (other than forestry and fisheries) accounts for only about 15\% of GDP, it employs 55\% of the workforce [ref]. Moreover, according to the 2011 census $69 \%$ of the population remains rural and intimately connected to this sector. There are also important forward and backward linkages to agriculture from the rest of the economy.

Our primary interest in this sector, however, is from the perspective of poverty which remains widespread despite significant progress in reducing it - the country is still estimated to have a third of the world's poor. According to some estimates $32.7 \%$ of the population is below the international poverty line of US\$ 1.25 per day (PPP) while $68.7 \%$ live on less than US\$ 2 per day (World Bank 2011) ${ }^{1}$. A key aspect of poverty is its incidence which is rural and concentrated among agricultural labour. Thus, according to the Indian Planning Commission, in the year 2009-10 more than 1 in 3 of the rural population was poor (33.8\%) whereas the figure for urban areas was about 1 in $5(20.9 \%)$. Equally important for our analysis, nearly $50 \%$ of agricultural labourers were below the poverty line in rural areas (GoI 2012).

1 The definition and measurement of poverty in India is controversial and politically charged and somewhat of an obsession with Indian economists. We do not enter into this area other than providing illustrative numbers for purposes of our argument. 
Within agriculture we focus on two key food crops, namely, rice and millets. Using district level panel data on annual yields (output per hectare), inputs, and climate variables for 196699, we find significant impacts of rainfall and temperature on yields of both crops.

Extrapolating forward, we find climate change is likely to reduce yields of these crops significantly $^{2}$. We also focus on regional variations in our results to highlight the uneven impact of climate change across India. The latter finding has policy implications in terms of regional imbalances and also for the literature on convergence and divergence across Indian states $^{3}$.

Our methodology is based on estimating an agricultural production function with exogenous climate variables, namely, precipitation and temperature. Thus, we eschew crop simulation approaches that rely on experimental data ${ }^{4}$. We do not also estimate reduced form relationships between economic variables such as profits or the monetary value of yield and various forms of weather measures.

Our focus on rice and millets is deliberate. The former is the most important cereal food crop in India accounting for $23.3 \%$ of gross cropped area and about $43 \%$ of total food grain production as well as $46 \%$ of cereal production (Singh 2009). In economic terms, rice (including paddy) ranked highest by value among all agricultural products in India with a total output of about $\$ 38.4$ billion in 2010 (FAO 2011a). India is considered to be one of the original centers of rice cultivation covering 44 million hectares. Its rice harvesting area is the largest in the world. Around $65 \%$ of the total population in India eats rice and it provides the main source of income and employment for more than 50 million households (IRRI).

\footnotetext{
${ }^{2}$ This is consistent with Guiteras (2009).

${ }^{3}$ See for instance Kalra and Sodsriwiboon (2010) and Purfield (2006).

${ }^{4}$ This approach is interestingly referred to as 'production function' approach a la Deschênes and Greenstone (2007) and Guiteras (2009). A comprehensive discussion of the pros and cons of this approach is found in Schlenker and Roberts (2009). For examples of the hedonic approach (also known as the Ricardian approach) which focuses on variations in land prices or profits see the seminal paper by Mendelsohn et al. (1994). This paper has spawned an extensive literature across several countries. Early applications of the Ricardian approach to India are Dinar et al. (1998) and Kumar and Parikh (2001). A recent application to Africa (Ethiopia) is Deressa and Hassan (2009).
} 
From our perspective of rural poverty in particular, we note rice (actually paddy) ${ }^{5}$ as cultivated in most parts of India, is a highly labour intensive crop. Also, much of this labour especially during sowing and transplanting is provided by women. Thus, there is an important gender dimension as well (FAO 2004 and FAO 2011b) ${ }^{6}$.

Millets on the other hand are traditional 'coarse cereals' whose importance is more in terms of their role as a staple crop consumed by the poor $^{7}$. In terms of food grain production millets ranked fourth in India behind rice, wheat and maize (FAO 2011a) ${ }^{8}$. Within millets we concentrate on the two key varieties, namely, pearl millet (bajra) and sorghum (jowar). Post Green Revolution, millets have lost ground to other food crops, especially wheat and rice--the production of millets has more or less remained constant between 1966-2006 whereas that of rice and wheat has increased by $125 \%$ and $285 \%$, respectively (MNI et al., 2009).

Table A1 provides normal (averaged over 2005-06 to 2009-10) area, production and yield of foodgrains in India. As the table shows, rice and wheat now account for more than three fourths of foodgrain output in India with 'coarse cereals' contributing only about one sixth (16 percent). But as late as 1970 the picture was quite different--the contribution to foodgrain output of rice, wheat and 'coarse cereals' in 1970-71 was respectively, 39\%, 22\% and 28.2\%. As we discuss later and anticipating our empirical results, this has important policy implications vis-à-vis climate change —we find millets in particular to be much less sensitive to temperature and rainfall than rice and by corollary more climate resilient.

\footnotetext{
${ }^{5}$ Paddy (Oryza sativa) is the rice grain with husk (which is also known as rice hull). Paddy becomes rice after the removal of husk by threshing. In 2010 India produced approx. 143 million tons of paddy and about 95 million tonnes of rice (FAO 2012). Rice husk is mainly used as fuel in boilers in rice mills.

${ }^{6}$ Conversely, in Asia (and in sub-Saharan Africa), women who are employed are more likely to be employed in agriculture than in other sectors--almost 70 percent of employed women in Southern Asia work in agriculture (FAO 2011b).

${ }^{7}$ In India 'coarse cereals' (a loaded and highly normative term) comprise millets, barley and maize (Table A1). Millets in turn primarily comprise pearl millet (bajra) and sorghum (jowar) which dominate in area and production. This is followed by finger millet (ragi) and small millets. Bajra, jowar and maize together account for over $90 \%$ each of area and production of 'coarse cereals' in India (Table A1).

${ }^{8}$ This was a distant fourth rank, however-production of these four crops in 2010 was, respectively, 95, 81, 14.1 and 13.3 million tons (FAO 2011a). By value too, millet output was about $\$ 2.3$ billion for the same year (compared to $\$ 38.4$ billion for rice).
} 
Again, from a poverty perspective both rice and millets are largely grown by small and marginal farmers (i.e., those with holdings less than 2 hectares) and with much less irrigation as compared to wheat which is almost entirely irrigated and cultivated by relatively bigger farmers. Table A2 shows $57 \%$ of area under rice is cultivated by marginal and small farmers compared to $44 \%$ for wheat. At the other end of the spectrum large wheat farmers (holdings of 10 hectares or more) account for more than $10 \%$ of the area under their crop compared to similar large rice farmers who account for only about $5.5 \%$ of the area under rice. Finally, $90 \%$ of area under wheat is irrigated compared to $59 \%$ for rice and only $29 \%$ for other cereals (coarse cereals).

The plan of the paper is as follows. The following section provides the context in terms of projected trends and regional variation in climate variables (rainfall and temperature) for India. It also provides further detail on how, when and where our two crops are grown in the country and the potential role of climate variables. Section 3 presents our conceptual framework and situates it in the literature on the impact of climate on agriculture, particularly with regard to India. Section 4 describes the data and econometric methodology. Section 5 presents and interprets the results of our analysis including the likely effect of climate change. Section 6 concludes the paper.

\section{Climate change and agriculture in India}

\section{$\underline{2.1 \text { Trends and regional variation in climate variables }}$}

India's climate system has unique features that are often not well captured by global climate models, the most widely used being coupled atmosphere-ocean-sea-ice-land-surface models (AOGCMs) with a resolution of 250-300 km grids. India's climate is dominated by the summer or southwest monsoon (and to a lesser extent the winter or northeast monsoon) and by the country's physiological features such as the western and eastern ghats, the central plateau and the Himalayas. The summer monsoon and the rains that it brings are a major weather phenomenon in the Indian subcontinent and deeply influences the lives of its inhabitants. It is a four-month period (June-September) when massive convective thunderstorms dominate India's weather, and is the Earth's most productive wet season (Collier and Webb 2002). This season provides over 80\% of India's rainfall (Bagla 2006, 2012). Thus the quantity, temporal and spatial distribution of the precipitation (rainfall) accompanying the monsoon is its most monitored component and is particularly important for 
agriculture. The summer monsoon is also the most economically important weather pattern to the extent a recent Indian Finance Minister (Pranab Mukherjee) called it "the real finance minister"9 . Yet it is "only partially understood and notoriously difficult to predict" (Wikipedia 2012).

Though the dependence of agriculture on the summer monsoon has reduced somewhat lately due to increased irrigation and better drought management, Figure 1 shows clearly how the two have marched in lockstep. This is unsurprising since, out of the total net sown area of 141.0 million hectares (Mha) in India, rainfed area accounts for 85.0 Mha spread over 177 districts. This constitutes approximately 60 percent of the total farming area in the country. Rainfed agriculture contributes $44 \%$ of the total food grain production of the country and produces $75 \%$ of pulses and more than $90 \%$ of sorghum, millet and groundnut from arid and semiarid regions. Even after half a century of lopsided policies that have focused on pockets of the country and specific crops, rainfed regions provide livelihood to nearly $50 \%$ of the total rural workforce and sustain $60 \%$ of cattle population of the country (MNI et al., 2009).

Keeping in view the peculiarities of India's climate and of the summer monsoon in particular, in a recent exercise a regional climate model $(\mathrm{RCM})$ with $50 \mathrm{~km}$ resolution, namely, PRECIS was deployed to dynamically downscale global model simulations and superimpose regional details from India (GoI 2010). This exercise coupled with long instrumental records allows us to capture past trends and also make projections for key climate variables such as temperature and rainfall within the country at a disaggregated level.

As mentioned earlier, for India as a whole mean annual temperature shows a significant warming trend of 0.51 degrees Celsius per 100 years during the period 1901-2007 (Kothawale et al., 2010). More important, accelerated warming has been observed in the last approximately 40 years (1971-2007), mainly due to intense warming in the recent decade $1998-2007^{10}$. Increases in the mean have been accompanied by a rise in both maximum and minimum temperatures at the all India level—by 0.71 and 0.27 degrees Celsius, respectively,

\footnotetext{
9 "India cheers as monsoon arrives; hope of better farm output raised" Hindustan Times May 31, 2010.

${ }^{10}$ All four major Indian seasons, namely, summer/pre-monsoon, monsoon, post-monsoon and winter contribute to this trend. But the increase in winter and post-monsoon temperatures is most marked-by 0.80 and 0.82 degrees Celsius, respectively over the last hundred years (GoI 2010). This has significant implications for rice yields as noted below.
} 
per 100 years during the period 1901-2007. Also, as with mean temperature, there has been an acceleration in trends of both maximum and minimum temperatures during 1971-2007. At the regional level, the homogenous regions ${ }^{11}$ of east coast, west coast and the peninsula show an increasing trend in the frequency ${ }^{12}$ of hot days but northern India (north of 22 degree N) does not. With respect to the frequency of cold days, however, all seven homogenous regions show a decreasing trend (in the frequency of cold days).

With regard to precipitation, Indian monsoon rainfall from 1871-2009 shows only a slight negative trend. But there is significant spatial variation in these trends over this period. Also, there is an increase in extreme rainfall events and their intensities (GoI 2010, Sen Roy and Balling 2004).

Projections for climate in the medium-run for India seem to indicate it will be warmer and wetter but with significant regional variation. Overall there will be (i) an increase in average surface temperature by 2-4 degrees $\mathrm{C}$, (ii) changes in the distribution of rainfall (inter-temporal and spatial) during both monsoon and non-monsoon months, (iii) decrease in the number of rainy days by more than 15 days, (iv) an increase in the intensity of rainfall by $1-4 \mathrm{~mm} /$ day, and (v) an increase in the frequency and intensity of cyclonic storms (Ranuzzi and Srivsatava 2012)

\subsection{Rice and millets in India: key issues}

Rice is the most important food crop in India ${ }^{13}$. It accounts for $23.3 \%$ of gross cropped area and $43 \%$ of total food grain production as well as $46 \%$ of cereal production (Singh 2009). In economic terms, rice (including paddy) ranked highest by value among all agricultural products in India with a total output of about \$38.4 billion in 2010 (FAO 2011a). The production of rice alone has more than quadrupled from around 21 million tons in 1950 to 95 million tons in 2010.

There are three seasons for growing rice in India - autumn (pre-kharif), winter (kharif) and summer (rabi) — named according to the season of harvest (though all crops are not grown in

\footnotetext{
${ }^{11}$ A uniform or homogenous region is an area in which everyone shares in one or more distinctive characteristics, in this case climate.

${ }^{12}$ Defined as days per decade.

${ }^{13}$ This discussion is based on Singh (2009).
} 
all regions). Winter or kharif rice (sown during Jun-Jul and harvested in Nov-Dec) is the main growing season and accounts for $84 \%$ of the country's rice crop ${ }^{14}$. This is followed by summer rice (sown during Nov-Feb and harvested in Mar-Jun) at 9\% and autumn rice (sown during May-Aug and harvested in Sept-Oct) which accounts for 7\% of the rice crop.

Among millets, pearl millet (bajra) is the most widely grown type of millet followed by sorghum (jowar $)^{15}$. Because of its tolerance to difficult growing conditions such as drought, low soil fertility and high temperature, it can be grown in areas where other cereal crops, such as maize or wheat would not survive (Basavaraj et al. 2010). Pearl millet in India is grown as a single season crop. Cultivation predominantly takes place on marginal lands and unirrigated lands. It is also grown in a small area as summer crop under irrigation particularly in the northwestern states of India mainly as a fodder crop. Area trends of pearl millet in India are constantly declining. Between 1972-73 and 2004-05, nearly 3 million ha has been diverted from pearl millet cultivation to other crops. Pearl millet production is concentrated in Gujarat, Maharashtra and Rajasthan which account for $70 \%$ of production in India. These states also have the highest concentration of pearl millet consumers since bulk of the consumption for food use takes place in the growing areas.

\section{Framework and relevant literature}

\subsection{Conceptual framework}

Our methodology is based on estimating an agricultural production function with exogenous climate variables, namely, precipitation and temperature. Our analysis is at the district level using a panel dataset for physical yield (output per hectare - gross cropped area) for rice and pearl millet. Thus, we eschew crop simulation approaches that rely on experimental data. We do not also estimate reduced form relationships between economic variables such as profits or the monetary value of yield and arbitrary forms of weather measures.

\section{$\underline{3.2 \text { Relevant literature }}$}

Several studies have looked at the impact of climate related variables on crop yields specifically for India. Lahiri and Roy (1985) (L-R) look at the supply response of rice yields

\footnotetext{
${ }^{14}$ As can be noted sowing and transplanting of winter rice is during the summer monsoon (Jun-Sept).

15 This discussion is based on Basavaraj et al. (2010).
} 
at the all India level and also include monthly rainfall (either in the sowing season or in the growing season). The paper is in the agricultural economics tradition of acreage and yield response to price (and also to "supply shifters" such as rainfall) and models this response in a Nerlovian partial adjustment framework (for which they actually do not find evidence). L-R postulate a gamma distribution for the effect of rainfall on yield (right skewed and bounded at zero), i.e., less rainfall (droughts) is worse than too much (floods). For yield they find the optimal monthly average rainfall is about $293 \mathrm{~mm}$ for the months of July and August. They also argue that with the spread of HYVs post-mid 1960s (1965 onwards) Indian agriculture has become more rainfall dependent esp. since water requirement has gone up and the spread of irrigation has not kept pace with it.

Kanwar (2006) extends this type of work to several food grains. He looks at supply response using a state level panel dataset and again finds rainfall matters considerably for supply response (it's a 'supply shifter') ${ }^{16}$. Auffhammer et al. (2012) extend Auffhammer et al (2006) and explicitly look at the impact of too little/too much rainfall (akin to gamma rainfall) on rice yields using a state level panel dataset. They too find significant impacts.

A problem in doing state or national level analysis is the need to aggregate rainfall and other weather data (there are several observation stations in a state) to one value at the state or national level. This is problematic since several Indian states are large, often bigger than countries in Europe and elsewhere ${ }^{17}$. Given the variation in rainfall and other weather variables for a state the resulting measurement error may bias the coefficients on weather variables downward Auffhammer et al. (2012).

As in this paper a district level panel dataset for India is used by Guiteras (2009) and also by Fishman (2011) and Krishnamurthy (2012). Guiteras (2009) examines the impact of temperature and rainfall on combined yield (in money terms) for five major food and one cash crop, namely, rice, wheat, jowar, bajra, maize and sugarcane. He finds that climate

\footnotetext{
16 "In other words, rainfall is the single most important factor determining supply response even today. Despite decades of massive irrigation schemes, the food crops continue to be rainfall-dependent." (op. cit., p. 80)

${ }^{17}$ For instance, the five biggest states of India, namely, Rajasthan, Madhya Pradesh (MP), Maharashtra, Andhra Pradesh (AP) and Uttar Pradesh (UP) range from 342,000 to 241,000 sq kms. The biggest state, Rajasthan is almost as big as Germany, whereas the next two (MP and Maharashtra) are almost the size of Poland and bigger than Italy and the Philippines each. AP and UP, respectively are bigger than or the same size as United Kingdom.
} 
change could reduce yields by 4.5 to $9 \%$ in the medium-run (2010-39) and by as much as $25 \%$ in the long-run (2070-2099) in the absence of long-run adaptation. The main drawback of Guiteras as highlighted by Sarker et al. (2012) and by Krishnamurthy (2012) is combining different crops which are impacted differently by climate change. The dependent variable is akin to district income (from 6 crops) ${ }^{18}$ normalised by area to arrive at gross revenue per hectare, and is hard to interpret.

Fishman (2011) also uses a district level panel and shows the impact of intra-seasonal variability of rainfall on yields. He shows that this effect can be moderated by spread of irrigation (so called adaptation) but the effect varies with groundwater depletion. Further, no evidence is found that irrigation mitigates increased heat exposure ${ }^{19}$.

\section{Data and methodology}

\subsection{Data sources}

4.1.1 Agricultural data- The data on the agricultural variables span the time period 19661999, and have been collected from the ICRISAT VDSA (Village Dynamics in South Asia) Apportioned Meso database. This is a district-level database, which includes information on crop area and production for several crops, irrigated area under different crops, land use, farm harvest prices, rainfall, livestock and agricultural implements, operational holdings, and population census data for 16 states of the country. The boundaries of the districts included in this database are defined as of 1966, i.e. any data on districts that were created after 1966 are given 'back' to the parent districts from which the newer districts were created. The final database thus includes data on the parent districts only, which is inclusive of the data 'apportioned' amongst the districts created later.

The variables of interest in this database include the area under, and production of, rice, pearl miller and sorghum (measured in hectares and tons respectively), district-wise consumption of fertilizers (tons of nitrogen, phosphate and potash fertilizers used), total gross cropped area in each district (measured in hectares, and accounting for multiple cropping), gross irrigated

\footnotetext{
${ }^{18}$ As stated by Guiteras (op. cit.) "these comprise roughly $75 \%$ of total revenues." (p. 9 footnote 6 ).

${ }^{19}$ Inter alia, he uses a quadratic time trend $f_{s}(t)$ which is state specific - it reflects technological progress and productivity gains, which are allowed to differ from state to state because of the large variance in agricultural performance across India.
} 
area under each of the three crops (measured in hectares, again accounting for multiple cropping), and total agricultural labour of each district. While the data on the area and production have been compiled into the ICRISAT database from the Statistical Abstracts of India, State Statistical Abstracts and the State Season and Crop reports, the data on fertilizer consumption has been obtained from the Fertilizer Statistics for India. The agricultural labour data has been procured from the decadal population censuses. Barring data gaps for a few variables in some districts, the area, input and output-related data is available at an annual frequency for both crops, whereas the data on agricultural labour is only available for the census years in the relevant range (1971, 1981, and 1991). For the other years in the sample, this data has been interpolated (by fitting a linear trend on population growth).

The dependent variable considered is the logarithm of yield (tons of output per hectare), for each of the three crops. The three main independent variables created from the list of ICRISAT variables are fertiliser consumption, labour consumption, and irrigation. Since information on fertiliser consumption is only available at the district level in overall form (i.e. for all crops combined), this variable had to be made relevant for the two crops in question. This was done by weighing total fertiliser consumption in a district by the ratio of area under the crop to the gross cropped area of that district (assuming uniform distribution of fertilisers over the cropped area). Similarly, data on labour consumption is also available at the overalllevel for each district. The same weight was applied to total labour consumption of a district, to create the labour variables for the crops. The irrigation variable has been created by taking the ratio of gross cropped area under rice/ millet to the gross cropped area in the entire district. The fertilizer consumption and labour consumption variables, in turn, have been divided by the total area under the crop.

4.1.2 Climate data- The climatic data has been procured from the India Water Portal domain (www.indiawaterportal.org). The portal contains 102 years of climatic data for the districts of India, which includes monthly data on precipitation, temperatures, cloud cover, humidity, and ground frost frequency, for example. The database that is used to compile this meteorological dataset is the publicly available Climate Research Unit (CRU) TS2.1 dataset, out of the Tyndall Centre for Climate Change Research, School of Environmental Sciences, University of East Anglia in Norwich, UK. This dataset consists of interpolated (on 0.5 degree latitudelongitude grid) global monthly data on variables such as rainfall and temperature from 1901 
to 2002. The CRU data was transformed to the district level by simple linear averaging from the gridded data of the CRU dataset.

Two independent variables have been created using this database, i.e. rainfall and temperature. In case of rice, the rainfall variable has been defined as the total growing-season precipitation for a given district, i.e. total rainfall in the months of June, July, August and September (Deschenes and Greenstone 2007 and Guiteras 2009). The rainfall in the growing season/ during transplantation of the crop is found to contribute immensely to the growth of the rice crop, especially the Kharif crop, which comprises about $84 \%$ of the total rice output of the country. The temperature variable for rice has been defined as the average of the maximum temperatures in the months of November and December of each year, normalized by long-term (1901-1999) average of the maximum temperatures for these two months, divided by the long-term standard deviation of the maximum temperature for these two months. When seasonal variations are present within a set of data, it is useful to express the data in terms of standardized anomalies. Moreover, standardized/normalised variables generally provide more information about the magnitude of anomalies in the data, because influences of dispersion have been removed. The average of the maximum temperatures in the months of November and December has been used, as it is the maximum temperature (especially at night) which during the time of harvest is found to affect the yield of rice significantly. In the case of pearl millet and sorghum, the rainfall variable is the (normalised) total annual rainfall for a given district, whereas the temperature variable is the (normalised) annual average of the average temperature. Both climactic variables have also been used in the quadratic form (defined as temp ${ }^{2}$ and rain $^{2}$ ), to understand the incremental impact of rainfall and temperature on the yield of all three crops. Table A3 provides summary statistics of the main variables used in the analysis.

\section{$\underline{4.2 \text { Methodology }}$}

In the case of rice, 102 districts were chosen across the top 9 rice producing states of the country (West Bengal, Andhra Pradesh, Uttar Pradesh, Tamil Nadu, Orissa, Madhya Pradesh, Karnataka, Punjab, and Bihar) ${ }^{20}$. In case of pearl millet, 69 districts were chosen amongst

\footnotetext{
${ }^{20}$ These nine states account for about $90 \%$ of the total production of rice in India, as of 1995 . Adding additional states to the sample does not increase this proportion significantly. The top 102 districts have been chosen in a manner so as to account for about $80-85 \%$ of the output of rice in each state (adding extra districts to the sample increases this proportion only marginally).
} 
the top 9 pearl-millet producing states of India (Rajasthan, Gujarat, Maharashtra, Madhya Pradesh, Karnataka, Andhra Pradesh, Tamil Nadu, Orissa and Haryana) ${ }^{21}$, whereas for sorghum the top 58 producing-districts were chosen amongst the top seven states (Maharashtra, Madhya Pradesh, Karnataka, Andhra Pradesh, Tamil Nadu, Gujarat and Rajasthan). Table A4 in the appendix lists the districts considered in each state for the three crops. As previously mentioned, the districts included in the ICRISAT database are those that existed as of 1966. However, the climatic dataset has been created taking into account the district boundaries as of 2002, which are remarkably different from those of 1966 . The districts that comprise the panel-sample have been selected on the basis of the districts that existed in the ICRISAT database, and the climatic variables for these districts have been approximated by the district to which the largest area of the parent district was allocated (provided that it is more than $50 \%$ of the total area of the parent district).

In the presence of AR (1) serial autocorrelation (the outcomes are correlated across years for a given district) and cross-sectional dependence (the outcomes are correlated across districts in a given year), along with heteroscedasticity, FGLS (feasible generalised least squares) with fixed effects was found to an appropriate method of estimation. However, one of the drawbacks of FGLS estimation is that it produces overly optimistic standard error estimates. Moreover, the estimates are only feasible if $\mathrm{N}<\mathrm{T}$, i.e. the number of observations are less than the number of time period, which is not the case for any of the three crops. To correct for this, panel-corrected standard error (PCSE) estimates are obtained, where the parameters are estimated using a Prais-Winsten (or OLS) regression. Equations have been estimated with district and year fixed effects, and district fixed effects and district-by-year fixed effects.

In the case of rice, it was observed that that the errors exhibited the presence of heteroscedasticity, serial autocorrelation, and also contemporaneous correlation. A Prais Winsten regression was thus estimated, under two different assumptions on correlation:

1) Within panels, there is AR (1) autocorrelation and that the coefficient of the AR (1) process is common to all of the panels, and

2) Within panels, there is AR (1) autocorrelation and that the coefficient of the AR (1) process is specific to each panel (i.e. panel-specific AR (1) autocorrelation)

\footnotetext{
${ }^{21}$ The states considered for pearl millet and sorghum account for nearly the entire output of these crops, while the districts known to be the largest producers have been chosen.
} 
However, in the case of pearl millet, the errors were found to exhibit heteroscedasticity, but no serial autocorrelation or contemporaneous correlation, whereas for sorghum, the errors exhibited heteroscedasticity, and contemporaneous correlation, but no serial correlation. A linear panel-data regression was then estimated, under the different assumptions on autocorrelation than which held for rice.

The regression equations which are estimated all three crops are as follows:

$$
\begin{gathered}
\operatorname{Ln}\left(\text { YIELD }_{i t}\right)=\boldsymbol{\alpha i}+\gamma_{\mathrm{t}}+\mathbf{X}_{\mathrm{it}}{ }^{\prime} \boldsymbol{\beta}+\sum \boldsymbol{\varepsilon}^{*} \mathbf{f}\left(\mathbf{W}_{\mathrm{it}}\right)+\boldsymbol{\mu}_{\mathrm{it}}, \\
\operatorname{Ln}\left(\mathbf{Y I E L D}_{\mathrm{it}}\right)=\boldsymbol{\alpha}_{\mathrm{i}}+\boldsymbol{\varepsilon}_{\mathrm{t}^{*}} \mathbf{t}+\mathbf{X}_{\mathrm{it}}{ }^{\prime} \boldsymbol{\beta}+\sum \boldsymbol{\varepsilon}^{*} \mathbf{f}\left(\mathbf{W}_{\mathrm{it}}\right)+\boldsymbol{\mu}_{\mathrm{it}, \text { and }}
\end{gathered}
$$

where $\alpha_{i}$ refer to the district-level fixed effects, which are quite useful in capturing unobserved heterogeneity across districts and $\gamma_{\mathrm{t}}$ refer to the year-specific dummies which control for annual differences in yield, common to all the districts (Deschenes and Greenstone, 2007). The second equation estimates the same equation, but with district-byyear fixed effects, rather than simple year fixed effects. The Xit refer to the district and yearspecific agricultural variables, whereas the Wit refers to the climactic variables (namely rainfall and temperature). State and year fixed effects were not estimated, given that the sample size would be too small to run a robust panel-data estimation.

\section{Results}

\section{$\underline{5.1 \text { Rice }}$}

Tables 1 and A5 (in the appendix) give the results the regression estimation for rice, taking the temperature variable as the average of the maximum temperatures in the months of November and December, and defining the rainfall variable as the total growing season (June, July, August and September) rainfall. Table 1 gives the regression results with district and district-year fixed effects, while table A5 gives the results with district fixed effects, and year fixed effects. The former specification accounts for both district-specific time-invariant unobservable characteristics, and also for district-specific time-varying unobservable characteristics, that trend smoothly over the sample period. These tables give the results, assuming AR (1) serial autocorrelation exists. The results are robust, even if panel-specific AR (1) serial autocorrelation is assumed. For these results, refer to tables A6 and A7 in the appendix. The coefficients on the district and year fixed effects have been suppressed. 
Table 1: Rice with district level and district- year fixed effects

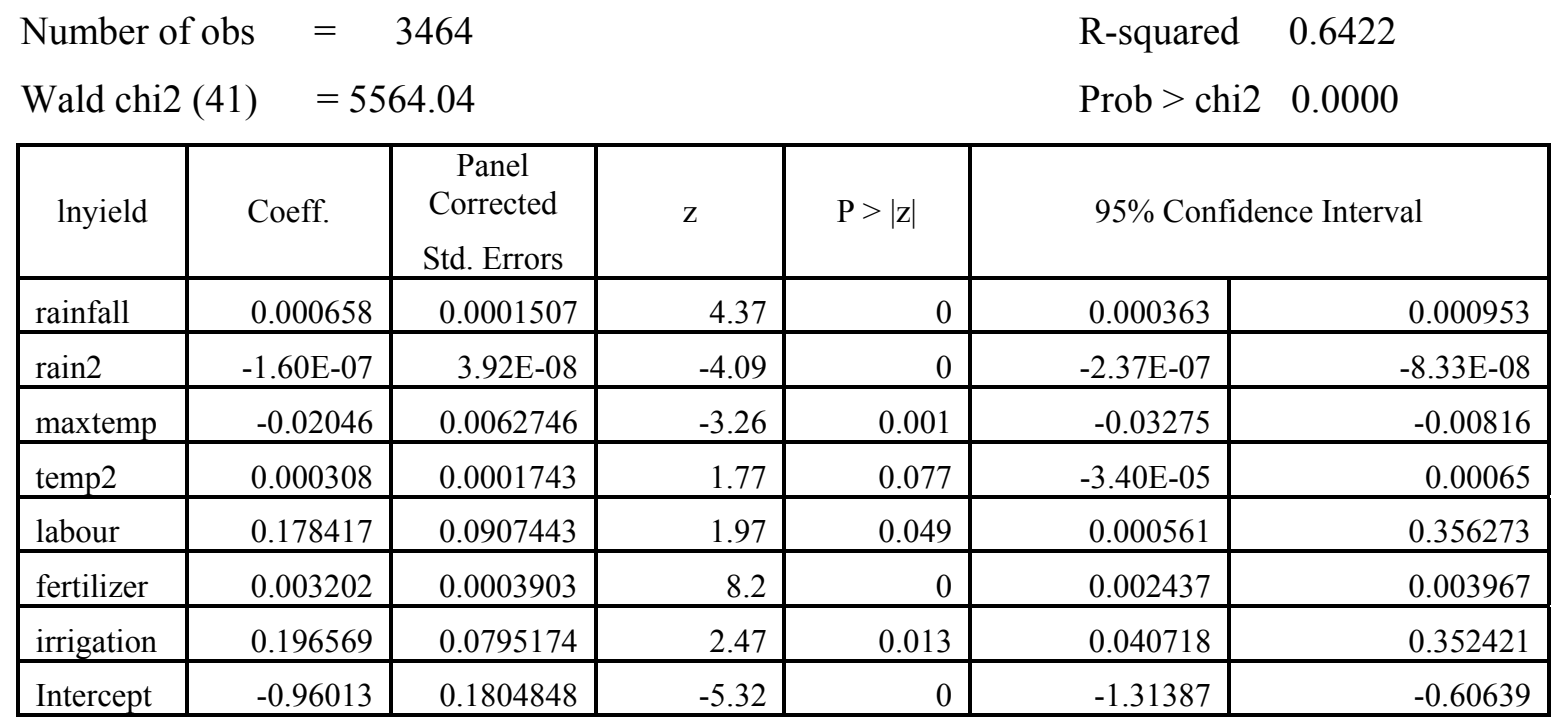

Table 1 reveals that with district and district-year fixed effects, both the rainfall and maximum temperature variables are found to be significant, even at the $1 \%$ level of significance. Higher rainfall leads to higher yield of rice, whereas higher temperatures lower the yield. The quadratic variable for rainfall is significant, and negative, which means that higher rainfall leads to higher yield, but at a decreasing rate. Interestingly, the coefficient on the quadratic term for temperature is positive: higher temperatures would mean lower yield rates, but the incremental impact of a one unit increase in the temperature variable becomes more severe as the temperature increases. Both the irrigation and fertilizer consumption variables are highly significant, which is expected given that rice production is highly inputdriven in large parts of the country, and the signs are intuitive (higher the proportion of land under rice irrigated, higher is the yield, and higher the fertilizer consumption used for rice, higher is the yield of rice). Labour too is found to have a positive impact on the yield of rice, even though the variable is slightly less significant (still significant at the $5 \%$ level). This particular specification is appropriate, given that it captures the effects of district-specific time-invariant unobservable characteristics, and also district-specific time-varying unobservable characteristics, that trend smoothly over the sample period.

Table A5 (in the appendix) captures the district and year fixed effects, without accounting for the time-varying unobservable factors. All the variables retain the same signs as in Table 1. The only difference is that labour now has a negative sign, which is counter-intuitive: more the labour consumption, lower is the yield of rice. Some variables are no longer significant, 
such as the temperature quadratic term, labour consumption, and the temperature term is significant only at the $10 \%$ level of significance. These results also hold once panel-specific errors are taken into account (tables A6 and A7 in the appendix).

\subsection{Pearl millet (bajra)}

Tables 2 and A8 (in the appendix) produce similar results for pearl millet as for rice, with the difference being in the definition of the climactic variables. Rainfall has been defined as the (standardized, using long term mean and standard deviation) total annual rainfall for each district, while temperature has been defined as (standardized, using long term mean and standard deviation) average annual temperature. Due to lack of serial correlation in the data, the errors are assumed to be independent in this case. Table 2 gives the results for district and district-year fixed effects, while table A8 (in the appendix) gives results with district fixed effects and year fixed effects. The coefficients on fixed effects have been suppressed.

Table 2: Pearl Millet with district-level and district-year fixed effects

\begin{tabular}{|c|c|c|c|c|c|c|}
\hline Number o & bs $=$ & 2282 & & & R-squared & 0.6464 \\
\hline Wald chi2 & 75) $=$ & 5567.92 & & & Prob $>$ chi 2 & 0.0000 \\
\hline lnyield & Coeff. & $\begin{array}{c}\text { Panel Corrected } \\
\text { Std. Errors } \\
\end{array}$ & $\mathrm{z}$ & $\mathrm{P}>|\mathrm{z}|$ & 95\% Confide & ence Interval \\
\hline rainfall & 0.135329 & 0.011123 & 12.17 & 0 & 0.113529 & 0.157129 \\
\hline rain2 & -0.0609 & 0.008664 & -7.03 & 0 & -0.07788 & -0.04392 \\
\hline avgtemp & -0.00034 & 0.097327 & 0 & 0.997 & -0.19109 & 0.190422 \\
\hline temp2 & -0.13075 & 0.145426 & -0.9 & 0.369 & -0.41578 & 0.15428 \\
\hline irrigation & -1.11178 & 0.405889 & -2.74 & 0.006 & -1.90731 & -0.31625 \\
\hline fertilizer & 0.003491 & 0.000499 & 7 & 0 & 0.002513 & 0.004469 \\
\hline Labour & -0.26723 & 0.11032 & -2.42 & 0.015 & -0.48345 & -0.05101 \\
\hline Intercept & -0.81681 & 0.083299 & -9.81 & 0 & -0.98007 & -0.65355 \\
\hline
\end{tabular}

Table 2 reveals a similar impact of higher rainfall on pearl millet production, as in case of rice (greater the rainfall, higher the yield). The variable is also found to be highly significant. While the average temperature variable is (highly) insignificant, the sign is intuitive. The sign of the rainfall quadratic term is identical to that of rice (higher rainfall means that the incremental impact of rainfall on pearl millet yield declines), however the sign of the temperature quadratic is negative: higher temperatures mean that the incremental impact of temperatures on pearl millet yield is dampened. It is also highly insignificant. The impact of 
the other agricultural variables appears to be significantly diluted in case of pearl millet: both labour usage and irrigation seem to have a negative impact on the yield of rice, even though they are significant at the $5 \%$ level of significance.

Table A8 gives mostly similar results to table 2, in terms of the signs and significance of the climactic variables. The difference in the agricultural control variables is that the fertilizer variable is now insignficant. Labour consumption and irrigation still have a negative impact on the yield of pearl millet, whereas fertilizer consumption has a positive impact. Another difference from table 2 is that the quadratic term for temperature (though insignificant) has a positive sign: as temperatures increase, yield of pearl millet declines; moreover, the negative impact is getting exacerbated over increases in temperature. The coefficient for quadratic for rainfall retains its positive sign.

\section{$\underline{5.3 \text { Sorghum (jowar) }}$}

Tables 3 and A9 (in the appendix) present the results for sorghum, assuming the same dependent variable as for the other two crops, while defining the climactic variables in a similar manner as was done for pearl millet. Similar to pearl millet, there is a lack of serial correlation in the data, hence the errors are assumed to be independent. Table 3 gives the results for district and district-year fixed effects, whereas table A9 (appendix) gives results with district fixed effects and year fixed effects. The coefficients on the fixed effects have been suppressed.

Table 3: Sorghum with district and district-year fixed effects

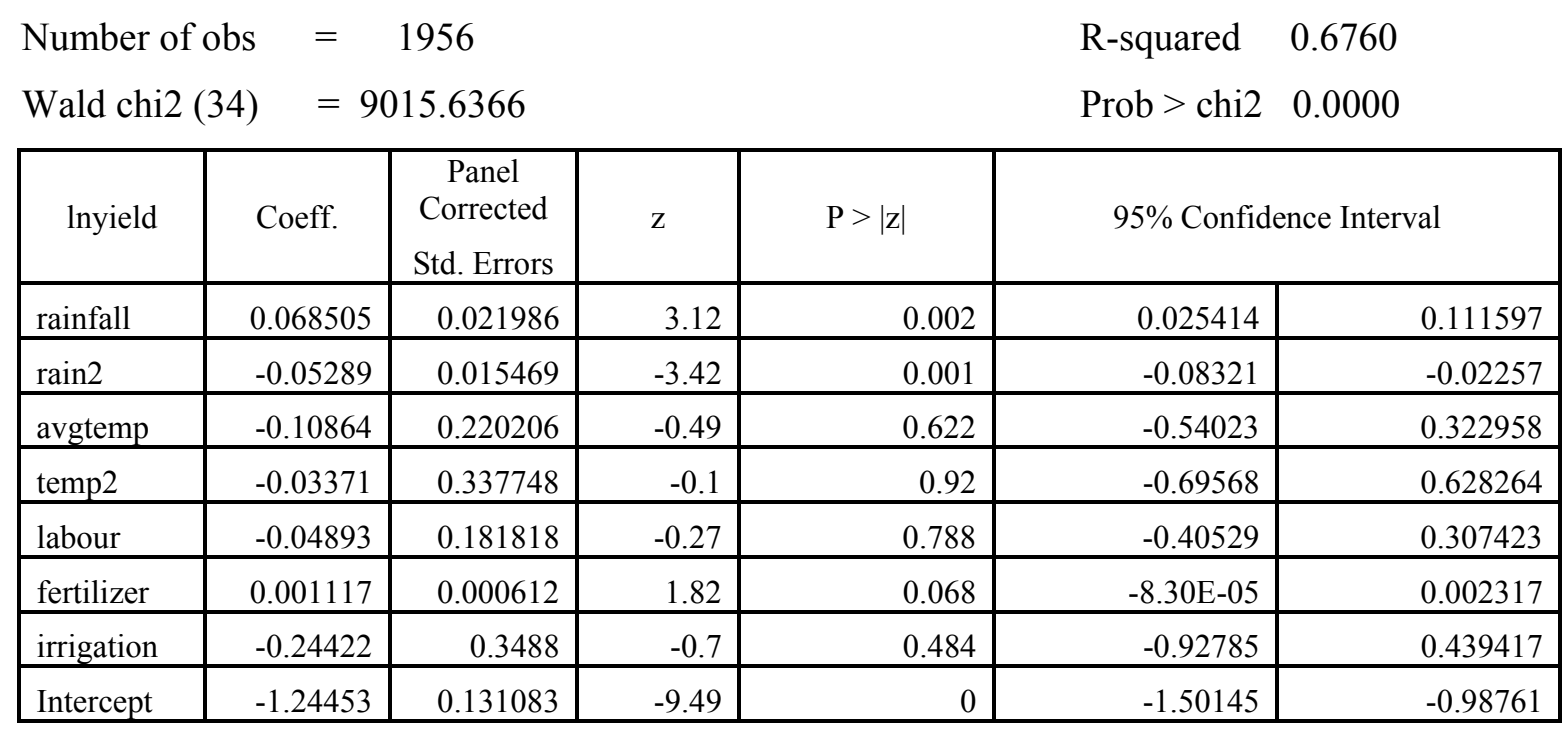


According to Table 3, the climactic variables seem to have similar effects on the yield of sorghum as they did on the other two crops. Higher rainfall means higher the yield, higher the average temperature, lower the yield. Higher the temperature, lower the rate of decrease of yield with temperature (as was the case with pearl millet), and higher the rainfall, lower the rate of increase of yield with rainfall. However, the temperature variables are found to be highly insignificant. Moreover, the agricultural control variables seem to have counterintuitive signs, i.e. higher the labour or irrigation, lesser is the yield of sorghum; these variables are also insignificant. Table A9 also gives similar results, with respect to the signs of the variables, other than the fact that fertilizer consumption is found to have a negative impact on yields, while irrigation is found to have a positive impact. The fertilizer and irrigation variables are highly insignificant, along with the temperature variable, while even labour is insignificant at the $5 \%$ level of significance.

\section{$\underline{5.3 \text { Regional differences }}$}

The regressions for rice, pearl millet and sorghum were also run using region-level interactive terms, to gauge the impact of rainfall and temperature on specific regions. These regions have been decided on the basis of geographical proximity, and similarity of climate, agricultural conditions, etc. The states comprising the sample for the three crops have been divided as follows:

Rice:

West Bengal and Bihar- Eastern region

Punjab and UP- Northern region

MP and Orissa- Central region

AP, Karnataka and Tamil Nadu-Southern Region

Pearl Millet (bajra):

Haryana, Rajasthan and UP- Northern region

Gujarat, MP and Maharashtra- Central region

AP, Karnataka and Tamil Nadu-Southern Region

Sorghum (jowar):

Rajasthan- Northern region

Gujarat, MP and Maharashtra- Central region 
AP, Karnataka and Tamil Nadu-Southern Region

Table A10 (in the appendix) gives the results for rice, where the regression has been carried out using district and year fixed effects, along with the interactive terms between the region indicators and both the rainfall and temperature variables, assuming $\operatorname{AR}(1)$ serial autocorrelation. While the significance of the original climactic variables drops tremendously, this exercise is useful in understanding the differential impact of climate change across regions. The district and year fixed effect terms have been suppressed. Table A11 in the appendix gives the results once panel-specific AR (1) serial autocorrelation has been assumed.

Tables A12 and A13 in the appendix illustrate similar results for pearl millet and sorghum respectively, assuming heteroscedasticity, and no AR (1) serial autocorrelation. Again, the district and year fixed effect terms have been suppressed.

Tables A10 and A11 illustrate the differential regional impact of climate change in case of the rice crop. For instance, for the central region, the positive effect of higher rainfall on yield of rice has been exacerbated, i.e. the (net) coefficient on rainfall for the central region is higher than the overall coefficient. This means that yield in this region responds more, to a given change in rainfall. However, given that over time, rainfall has declined in this region, so would have the yield of rice. For the northern and eastern regions, the positive effect of more rainfall is dampened: it would lead to a lesser increase in yield, even though the final coefficient still remains positive. However, again given that the rainfall in these regions too has declined over time, it seems fair to say that the reduction in yield would not be as much as it would be at the overall level. Similarly, in case of temperature, for the southern and eastern regions, the negative impact of higher temperatures on rice yield is getting dampened: in case of the southern region, the final effect has still remained negative, while in case of the eastern region, the final effect has turned positive! Given that temperatures have been rising in both eastern and southern India, this means that while the yield of rice in southern India has fallen less than it has at an overall level (even though it has still fallen), the yield of rice in eastern India has actually gone up due to higher temperatures. Conversely, in central India, the negative impact of higher temperatures on yield has only been worsened: higher temperatures would reduce yield even further in central India than they would at an overall level. 
Tables A12 and A13 also gives some interesting results: in the central and northern regions, the positive impact of higher rainfall on the yield of pearl millet is getting strengthened: however, given that rainfall has declined in both these regions over time, the impact on yield of this crop in these regions would have been more negative than at an ovall level. For the temperature effects, in both southern and central India, the (net) effect of temperature on the yield of pearl millet is turning positive. This bodes well for the pearl millet crop, if temperatures have been rising in both these regions of the country. Similarly, in case of sorghum, the net effect of rainfall on its yield remains positive in both the central and southern states, even though the (positive) effect is mellowed down. For the temperature variable however, it appears as if in the central states, the net effect is becoming positive, i.e. higher the temperature, higher the yield, whereas the effect remains negative for the three southern states (Tamil Nadu, AP and Karnataka). This is well-supported by evidence, which suggests that the yield of sorghum is negatively affected by declines in temperature.

\subsection{Interpretation of Regression Results}

In the case of rice, the results reveal the strong positive effect of rainfall on its yield, across different specifications of the regression equation. Moreover, the positive impact of rainfall on its yield is dampened, as the level of rainfall increases, or conversely, the negative impact of lesser rainfall on yields is exacerbated as rainfall reduces. Rainfall has deteriorated over time in most regions, other than the southern, which has experienced higher rainfall. Hence, in the sample considered, in 4 out of 9 states (MP, Orissa, West Bengal and Bihar), declining rainfall may be a contributing factor towards declining yields of rice. Incidentally, these are also some of the economically weaker states of the country.

The direction of impact of maximum temperature on the yield of rice is as expected- as temperatures increase, the yield of rice declines. Moreover, higher temperatures have meant that the rate of decline of yield with increase in temperature also increases. The regional effects are also interesting: in the states of AP, Karnataka, Tamil Nadu, West Bengal and Bihar, higher temperatures have not had as severe an impact on the yield of rice as at the overall level. In fact, in West Bengal and Bihar, they may even have had a slightly positive impact. However, in the states of MP and Orissa, higher temperatures have meant an even more severe decline in the yield of rice than at the overall level. 
The agricultural controls such as irrigation, labour and fertilizer consumption have positive and strong impact on the yields. Labour, however, is found to affect yield negatively when time-variant unobservable characteristics are not taken into account. This may be attributed to the surplus labour available for rice production in the country. Moreover, labour input intensity is higher in districts which are already poor in terms of yield, where yields may be falling irrespective of higher labour usage (which also explains the insignificance of this variable in these specifications).

The story of pearl millet is more subtle- the impact of rainfall on the yields remains identical to that in case of rice: higher rainfall leads to higher yields of the crop, albeit at a declining rate. Regionally, the declines in rainfall in both the central and northern regions over time have contributed to lowering the yields of this crop (in states like Rajasthan, UP, MP, Gujarat, Maharashtra and Haryana).

The effects of higher (average) temperature on the yield of pearl millet continue to remain negative, even though the variable turns out to be (highly) insignificant, pointing to the hardy nature of this crop. In states such as AP, Karnataka, Tamil Nadu, Gujarat, MP and Maharashtra, the response of yield to higher average temperatures is in net, positive. Such results seem to suggest the slightly weaker impact increases in temperature may have on the yield of pearl millet, than in case of rice: different regions would reveal different impacts on yield, depending on whether the average temperatures have risen or fallen.

The agricultural controls however exhibit interesting effects: the labour consumption variable has a negative impact on the yield of pearl millet (again, this might be attributed to the availability of surplus labour in the production of this crop). Irrigation, on the other hand, while an important factor in explaining the yield of the crop, has a negative impact on its yield with both district and year fixed effects, and district and district-by-year fixed effects. This is counter-intuitive. Fertiliser consumption, on the other hand, has the expected positive impact on the yield of pearl millet, even though it appears to be insignificant in one specification. Such results reinforce the notion of pearl millet being a crop that doesn't require much input application. In addition, it appears to withstand climate change better than crops such as rice. 
Sorghum, also considered as a 'hardy crop' much like pearl millet, seems to be more sensitive to decreases in rainfall, than to an increase in the average temperature (the temperature variable is insignificant) even though there is still a negative relationship between temperatures and sorghum yield. The agricultural control variables also show counter-intuitive trends with the sorghum yield. There is no consistent trend as far as these signs are concerned: different specifications of the model yield different signs for the irrigation and fertiliser variables, even though labour seems to have a consistent negative impact (again, possibly due to the availability of surplus labour). Moreover, these controls show up as insignificant in certain specifications. This points to the uncertainty surrounding the determinants of the yield of sorghum, much like pearl millet.

The regional effects indicate that states such as AP, Tamil Nadu, Karnataka, Gujarat, Maharashtra and Madhya Pradesh react in a similar manner to an increase in rainfall (i.e. when rainfall increases, the yield of sorghum will also increase). In the southern states, which have experienced an increase in rainfall over time, this may have contributed towards increasing the yield of sorghum. In states such as Gujarat, Maharashtra and Madhya Pradesh, which are some of the largest producers of the crop, the effect of average temperature on yields has been positive: however, it is difficult to say whether the crop would be able to withstand further increases in temperature in the future. For instance, in the southern states of Karnataka, AP and Tamil Nadu, higher temperatures have already begun showing negative effects on the yield.

\subsection{Climate Change Predictions}

An attempt has been made in this paper at predicting the impact of climate change on the yields of the three foodgrains. The climate change scenario considered for these forecasts is the short-term (2010-2039) A1F1 (business-as-usual) scenario for south Asia of the IPCC. This involves a $0.5{ }^{\circ} \mathrm{C}$ uniform increase in temperature, and a $4 \%$ increase in precipitation over the values in 1961-1990. While it is understandable that these predictions would not capture the differences in distributions of rainfall and temperature across different regions of the country, it is a start towards understanding the probable impact of climate change on yields.

For rice, the mildly positive impact of increasing precipitation on yield was outweighed by the negative impact of increasing temperatures on yield, both in the wettest and driest rice- 
producing areas (the entire population was divided into quartiles, on the basis of declining levels of rainfall). The expected decline in the yield of rice is $1.21 \%$ in the wettest areas, and $0.92 \%$ in the driest areas. However, in case of pearl millet, the yield of the crop is expected to increase across all quartiles of regions. The yield of sorghum is expected to decline across all regions, the decline being steepest in the wettest regions, where it is expected to go down $1.42 \%$. For details on the percentage change in the predicted yields of the crops, refer to the table A14 in the appendix.

These results reinforce some of the results of the regressions; rice appears to be susceptible to climate change, especially in the wettest and driest parts of the country. Whilst pearl millet appears to withstand climate change well (its yield is predicted to go up across regions), the yield of sorghum appears to decline, given the short-run expected climate change. The relative magnitude of temperature and rainfall changes appear to play a pivotal role in deciding the direction of change in the yield: evidence suggests that yields of crops such as pearl millet and sorghum may decline with a drop in temperature; the expected temperature increases may therefore be beneficial to these crops. However, that does not appear to be the case with sorghum; its yield is declining across regions. The extent of increase in the temperature appears to be more harmful to sorghum, than it is for pearl millet. On the other hand, the expected increase in rainfall is beneficial for all three crops. Thus, in the short-run scenario, more rainfall seems to be conducive to crop growth, whereas higher temperatures have an ambiguous effect on the yields.

\section{Concluding remarks}

Climate change is caused primarily through carbon emissions. In this nature does not discriminate. A ton of carbon (greenhouse gases more generally) burnt anywhere in the world and at any point in time, broadly speaking, causes the same increase in the stock of greenhouse gases. In other words, it is a stock externality caused by a uniformly mixed pollutant. But the effects (i.e., damages) of global warming are very asymmetric in nature. It is expected to affect, for instance, low-lying coastal areas more than areas inland. Indeed, some areas could gain from global warming--very cold areas could become habitable and cultivable. 
As mentioned in the Introduction, in this paper we wanted to look at the possible effects of climate change on certain crops in India. We have looked at rice and millets--the former is the leading foodgrain in terms of output and area sown, while the latter (group) is a hardy crop that can withstand the vicissitudes of weather.

For rice the evidence is overwhelmingly that both rainfall and temperature (the two climate variables) matter. But so do other inputs viz. labour, fertiliser and irrigation. For millets, rainfall is the sole determinant (that is statistically significant). If one takes the regressions seriously, millets grow on their own--none of the other variables matter.

There are now a number of recent studies that address the issues dealt with in this paper for India and other countries, for example (but not limited to) Deschenes and Greenstone (2007), Guiteras (2009), Fishman (2011), Auffhammer et al. (2006, 2012) and Krishnamurthy 2012. Our study has a monthly district-wise focus. We are able to analyse fixed effects emanating from district and state specific characteristics. Also unlike some studies (e.g., Auffhammer 2006, Schlenker and Roberts 2009, Poudel and Kotani 2012 and Sarker et al. 2012), where only temperature and/or rainfall appear on the right-hand side, we have a number of other inputs (controls) on the right hand side. These can give us some idea of the trade-offs involved in the process of climate change--if the temperatures rise, causing yields of paddy to fall, can it be compensated for by the use of more fertiliser? ${ }^{22}$ Our focus is also deliberately crop-based. There are studies where temperature is seen to cause changes in income (in a multi-crop setting). The interpretation of these can be problematic (joint outputs, no input variation, the use of prices). We set ourselves the limited task of tracking (carefully) the changing yields over a large panel. In that the crops of interest matter to the lives some of the world's poorest people, who would be affected by climate change, this analysis seems worthwhile.

\footnotetext{
22 This presupposes that the past is a good guide to the future, and no tipping points or other nonlinearities have been set in motion.
} 


\section{References}

Auffhammer, Maximilian, V. Ramanathan, and Jeffrey R. Vincent. 2012. "Climate change, the monsoon, and rice yields in India." Climatic Change, 111:411-424.

Auffhammer, Maximilian, V. Ramanathan, and Jeffrey R. Vincent. 2006. "Integrated model shows that atmospheric brown clouds and greenhouse gases have reduced rice harvests in India." Proceedings of the National Academy of Sciences (PNAS), 103(52): 19668-19672 (December 26).

Bagla, Pallava. 2012. "Drawing a bead on India's enigmatic monsoon." Science, 335(6071):910, 24 February.

Bagla, Pallava. 2006. "Controversial rivers project aims to turn India's fierce monsoon into a friend." Science, 313(5790):1036-1037, 25 August.

Barrios, Salavador, Bertinelli, Luisito, Strobl, Eric. 2006. "Climatic change and rural-urban migration: the case of sub-Saharan Africa." Journal of Urban Economics, 60(3): 357-371.

Basavaraj, G., P. Parthasarathy Rao, Shraavya Bhagavatula and Wasim Ahmed. 2010. "Availability and utilization of pearl millet in India." SAT eJournal (ejournal.icrisat.org): Vol. 8 (December):1-6.

Cagliarini, Adam and Anthony Rush. 2011. "Economic development and agriculture in India.” Reserve Bank of Australia Bulletin, June Quarter:15-22.

Cameron, Colin A. and Pravin K Trivedi. 2009. Microeconometrics Using Stata. College Station, Texas: StataCorp LP.

Collier, Michael and Robert H. Webb. 2002. Floods, Droughts, and Climate Change, Tucson, AZ: University of Arizona Press (published 1 November 2002)

Dell, Melissa, Benjamin F. Jones and Benjamin A. Olken. 2009. "Temperature and income: reconciling new cross-sectional and panel estimates." American Economic Review: Papers \& Proceedings, 99(2):198-204.

Deressa, Temesgen Tadesse and Rashid M. Hassan. 2009. "Economic impact of climate change on crop production in Ethiopia: evidence from cross-section measures." Journal of African Economies, 18(4):529-554.

Deschênes, Olivier and Greenstone, Michael. 2007. "The economic impacts of climate change: evidence from agricultural output and random fluctuations in weather." American Economic Review, 97(1):354-385.

Dinar, Ariel, Robert Mendelsohn, Robert Evenson, Jyoti Parikh, Apurva Sanghi, Kavi Kumar, James McKinsey and Stephen Lonergan. 1998. "Measuring the imapct of climate change on Indian agriculture.” Technical Paper 402, World Bank, Washington, D.C.

Fishman, Ram Mukul. 2011. "Climate change, rainfall variability, and adaptation through irrigation: evidence from Indian agriculture.” Columbia University. November. 
Food and Agriculture Organization (FAO). 2012. Rice Market Monitor, XV(1), January. Trade and Markets Division, FAO.

Food and Agriculture Organization (FAO). 2011a. FAOSTAT (FAO Statistical Database): http://faostat.fao.org/DesktopDefault.aspx?PageID $=339 \&$ lang $=$ en \&country $=100$ and (accessed 29.09.2012).

Food and Agriculture Organization (FAO). 2011b. The state of food and agriculture (201011): Women in agriculture: closing the gender gap for development. Rome.

Food and Agriculture Organization (FAO). 2004. Report of "Regional consultation on gender dimensions in Asian rice livelihood systems in the changing milieu of technologies and economy." held on March 9-12. Regional Office for Asia and the Pacific, Bangkok. RAP Publication 2004/13.

Government of India (GoI). 2012. "Press note on poverty estimates, 2009-10." Planning Commission. March.

Government of India (GoI). 2010. "Climate change and India: a 4 × 4 assessment-a sectoral and regional analysis for 2030s." Indian Network for Climate Change Assessment (INCCA), Ministry of Environment and Forests. November.

Guiteras, Raymond. 2009. "The impact of climate change on Indian agriculture." Mimeo. University of Maryland, College Park. September.

Hornbeck, Richard. 2012. "The enduring impact of the American dust bowl: short- and long-run adjustments to environmental catastrophe." American Economic Review, 102(4): $1477-1507$.

International Rice Research Institute (IRRI). "Rice in India." $\underline{\text { http://irri.org/index.php?option=com_k2\&view=item\&id=8744:rice-in-india\&lang=en }}$ (accessed September 30, 2012).

Kalra, Sanjay and Piyaporn Sodsriwiboon. 2010. "Growth convergence and spillovers among Indian states: what matters? What does not?" IMF Working Paper, WP/10/96 (April).

Kanwar, Sunil. 2006. "Relative profitability, supply shifters and dynamic output response, in a developing economy." Journal of Policy Modeling, 28:67-88.

Kothawale, D.R., A.A. Munot and K. Krishna Kumar. 2010. "Surface air temperature variability over India during 1901-2007, and its association with ENSO." Climate Research, 42:89-104.

Krishnamurthy, Chandra Kiran B. 2012. "The distributional impacts of climate change on Indian agriculture: a quantile regression approach.” Madras School of Economics Working Paper 69/2012 (May).

Kumar, Hemanshu and Rohini Somanathan. 2009. "Mapping Indian districts across census years, 1971-2001." Centre for Development Economics (Department of Economics, Delhi School of Economics) Working Paper No. 176 (April). 
Kumar, K.S. Kavi. 2009. "Climate sensitivity of Indian agriculture.” Madras School of Economics Working Paper 43/2009 (April).

Kumar, K.S. Kavi and Jyoti Parikh. 2001. "Indian agriculture and climate sensitivity." Global Environmental Change, 11(2):147-154.

Kumar, Krishna K., Rupa Kumar Kolli, R.G. Ashrit, N.R. Deshpande, and J.W. Hansen. 2004. "Climate impacts on Indian agriculture." International Journal of Climatology, 24:1375-1393.

Lahiri, Ashok and Prannoy L. Roy. 1985. "Rainfall and supply response: a study of rice in India.” Journal of Development Economics, 18(2-3):315-334.

Lal, Murari, T. Nozawa, S. Emori, H. Harasawa, K. Takahashi, M. Kimoto, A. Abe-Ouchi, T. Nakajima, T. Takemura and A. Numaguti. 2001. "Future climate change: implications for Indian summer monsoon and its variability." Current Science, 81(9):1196-1207 (November).

Mall, R.K., Ranjeet Singh, Akhilesh Gupta, G. Srinivasan and L. S. Rathore. 2006. "Impact of climate change on Indian agriculture: a review." Climatic Change, 78: 445-478.

Mendelsohn, Robert, William Nordhaus and Daigee Shaw. 1994. "The Impact of Global Warming on Agriculture: A Ricardian Analysis.” American Economic Review, 84(4):753771.

MNI (Millet Network of India), Deccan Development Society and FIAN (FoodFirst Information and Action Network), India. 2009. Millets: future of food and farming.

Peng, Shaobing, Jianliang Huang, John E. Sheehy, Rebecca C. Laza, Romeo M. Visperas, Xuhua Zhong, Grace S. Centeno, Gurdev S. Khush, and Kenneth G. Cassman. 2004. "Rice yields decline with higher night temperature from global warming." Proceedings of the National Academy of Sciences (PNAS), 101(27): 9971-9975 (July 6).

Poudel, Santosh and Koji Kotani. 2012. "Climatic impacts on crop yield and its variability in Nepal: do they vary across seasons and altitudes?" Climatic Change, published online May 23 (DOI 10.1007/s10584-012-0491-8).

Purfield, Catriona. 2006. "Mind the Gap-Is economic growth in India leaving some states behind?" IMF Working Paper, WP/06/103 (April).

Ranuzzi, Anna and Richa Srivastava. 2012. "Impact of climate change on agriculture and food security in India." ICRIER Policy Series, No. 16 (May). Indian Council for Research on International Economic Relations (ICRIER), New Delhi.

Sarker, Md. Abdur Rashid, Khorshed Alam and Jeff Gow. 2012. "A comparison of the effects of climate change on Aus, Aman and Boro rice yields in Bangladesh: evidence from panel data." Paper presented at the 41st Australian Conference of Economists (ACE), Victoria University, Melbourne, July 8-12. 
Schlenker, Wolfram and Michael J. Roberts. "Nonlinear temperature effects indicate severe damages to U.S. crop yields under climate change." Proceedings of the National Academy of Sciences (PNAS), 106(37): 15594-15598 (September 15).

Sen Roy, Shouraseni and Robert C. Balling Jr. 2004. "Trends in extreme daily precipitation indices in India.” International Journal of Climatology, 24(4):457-466, (March 30).

Singh, Madan Pal. 2009. "Rice productivity in India under variable climates." Paper presented at MARCO (Monsoon Asia Agro-Environmental Research Consortium) Symposium, October 6-9, Tsukuba, Japan. Workshop 2 (October 6).

Wikipedia. "Monsoon of Indian subcontinent."

http://en.wikipedia.org/wiki/Monsoon_of_Indian_subcontinent (accessed September 30, 2012).

World Bank. "Poverty \& equity databank and PovcalNet." http://povertydata.worldbank.org/poverty/country/IND (accessed September 30, 2012) and http://povertydata.worldbank.org/poverty/country/IND (accessed September 30, 2012). 


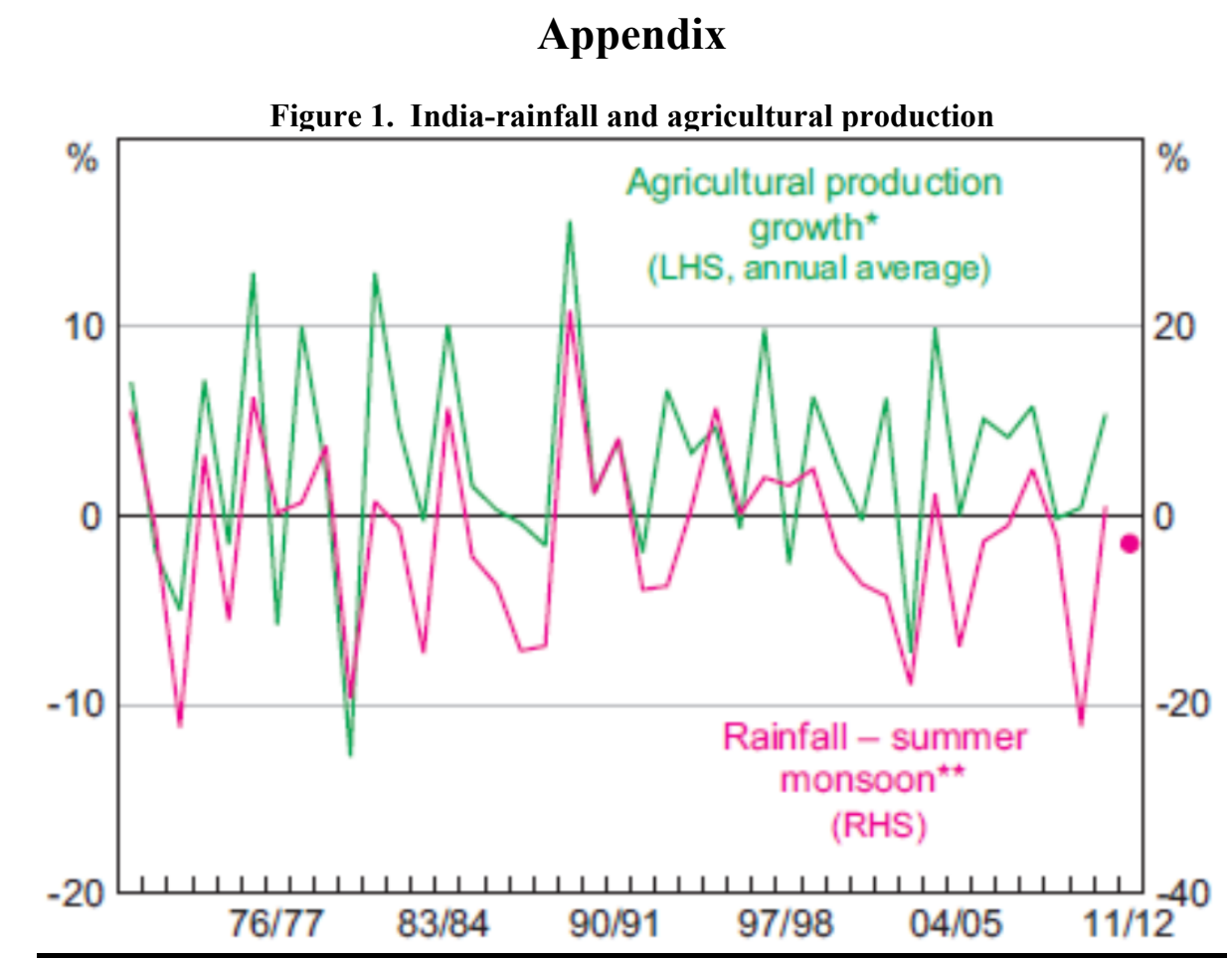

** Percentage deviation from long-run average.

Source: Cagliarini and Rush (2011) 
Table A1. Normal (average of 2005-06 to 2009-10) area, production and yield of food crops in India

Area - Million Hectares Production - Million Tonnes

\begin{tabular}{|c|c|c|c|c|c|c|c|}
\hline \multicolumn{8}{|c|}{ Yield - Kg./ Hectare } \\
\hline & Season & Area & $\begin{array}{l}(\% \text { of } \\
\text { total })\end{array}$ & Production & $\begin{array}{l}(\% \text { of } \\
\text { total })\end{array}$ & $\begin{array}{l}\text { (\% of total as } \\
\text { of } 1970-71)\end{array}$ & Yield \\
\hline \multirow{3}{*}{ Rice } & Kharif & 39.36 & & 80.38 & & & \\
\hline & Rabi & 4.41 & & 13.64 & & & \\
\hline & Total & 43.77 & 35.7 & 94.02 & 42.4 & (39) & 2148 \\
\hline Wheat & Rabi & 27.75 & 22.6 & 77.04 & 34.7 & (22) & 2777 \\
\hline \multirow{3}{*}{ Jowar } & Kharif & 3.43 & & 3.54 & & & \\
\hline & Rabi & 4.62 & & 3.79 & & & \\
\hline & Total & 8.05 & 6.6 & 7.33 & 3.3 & & 911 \\
\hline Bajra & Kharif & 9.26 & 7.5 & 8.29 & 3.7 & & 895 \\
\hline \multirow{3}{*}{ Maize } & Kharif & 6.96 & & 13.04 & & & \\
\hline & Rabi & 1.05 & & 4.00 & & & \\
\hline & Total & 8.01 & 6.5 & 17.04 & 7.7 & & 2128 \\
\hline \multirow{3}{*}{$\begin{array}{l}\text { Coarse } \\
\text { Cereals* }\end{array}$} & Kharif & 21.97 & & 27.32 & & & \\
\hline & Rabi & 6.31 & & 9.14 & & & \\
\hline & Total & 28.28 & 23.0 & 36.46 & 16.4 & (28.2) & 1290 \\
\hline \multirow{3}{*}{ Pulses } & Kharif & 10.65 & & 4.99 & & & \\
\hline & Rabi & 12.27 & & 9.32 & & & \\
\hline & Total & 22.92 & 18.7 & 14.31 & 6.5 & & 625 \\
\hline \multirow{3}{*}{ Foodgrains } & Kharif & 71.97 & & 112.70 & & & \\
\hline & Rabi & 50.74 & & 109.15 & & & \\
\hline & Total & 122.71 & 100.0 & 221.85 & 100.0 & & 1808 \\
\hline
\end{tabular}

*(Jowar, Bajra, Ragi, Small Millets, Barley and Maize)

Note: Figures in parentheses are shares in total foodgrain production in 1970-71

Source: Agricultural Statistics at a Glance, Directorate of Economics and Statistics, Department of Agriculture and Cooperation, Government of India (Adapted from table 4.3) 


\begin{tabular}{|l|r|r|r|r|r|r|r|r|r|r|r|}
\hline \multicolumn{10}{|c|}{ Table A2. Irrigated and unirrigated area by size classes under different food crops, 2005-06 } \\
\hline \\
\cline { 2 - 14 }
\end{tabular}

\begin{tabular}{|l|l|}
\hline Marginal & less than 1 hectare \\
\hline Small & $1-$ less than 2 hectares \\
\hline Semi-medium & 2 - less than 4 hectares \\
\hline Medium & $4-$ less than 10 hectares \\
\hline Large & 10 hectares or more \\
\hline
\end{tabular}

\begin{tabular}{|c|c|c|c|}
\hline Crop & $\%$ area marginal and small & $\%$ area large & $\%$ area irrigated \\
\hline Paddy & $56.6 \%$ & $5.6 \%$ & $58.9 \%$ \\
\hline Wheat & $43.8 \%$ & $10.4 \%$ & $90.0 \%$ \\
\hline
\end{tabular}

Source: Department of Agriculture and Cooperation, Agricultural Census Division 
Table A3. Summary Statistics

\begin{tabular}{|c|c|c|c|c|c|c|c|}
\hline \multirow{2}{*}{ Variable/Crop } & \multirow[b]{2}{*}{ Unit } & \multicolumn{2}{|c|}{ Rice } & \multicolumn{2}{|c|}{ Pearl Millet (Bajra) } & \multicolumn{2}{|c|}{ Sorghum( Jowar) } \\
\hline & & Mean & St. dev. & Mean & St.dev. & Mean & St.dev. \\
\hline Rainfall & $\mathrm{mm}$ & 850.58 & 398.83 & 804.92 & 358.69 & 884.84 & 411.57 \\
\hline $\begin{array}{l}\text { Normalised } \\
\text { rainfall }\end{array}$ & - & \multicolumn{2}{|c|}{ Not applicable } & 0.03 & 0.96 & 0.00 & 0.93 \\
\hline Temperature & ${ }^{\circ} \mathrm{C}$ & 27.51 & 1.40 & 26.36 & 1.67 & 26.25 & 1.24 \\
\hline $\begin{array}{l}\text { Normalised } \\
\text { temperature }\end{array}$ & - & 0.51 & 1.90 & 0.07 & 0.15 & 0.09 & 0.14 \\
\hline Area & 000 hectares & 202.15 & 163.93 & 126.58 & 161.66 & 174.16 & 148.71 \\
\hline Production & 000 tons & 324.47 & 328.28 & 60.28 & 69.87 & 116.59 & 106.84 \\
\hline $\begin{array}{l}\text { Fertiliser } \\
\text { consumption }\end{array}$ & tons/hectare & 58.08 & 55.31 & 43.38 & 44.45 & 39.20 & 44.92 \\
\hline $\begin{array}{l}\text { Labour } \\
\text { consumption }\end{array}$ & $\begin{array}{l}\text { labour in 000's } \\
/ \text { area }\end{array}$ & 0.49 & 0.34 & 0.35 & 0.31 & 0.37 & 0.28 \\
\hline Irrigation & - & 0.37 & 0.30 & 0.03 & 0.05 & 0.05 & 0.10 \\
\hline $\begin{array}{l}\text { Yield } \\
\text { (Production/area) }\end{array}$ & tons/hectare & 1.58 & 0.88 & 0.64 & 0.41 & 0.68 & 0.38 \\
\hline
\end{tabular}

Table A4. States and districts considered for each crop

\begin{tabular}{|c|l|}
\hline \multicolumn{2}{|c|}{ Rice } \\
\hline West Bengal & Burdwan, 24 Parganas, Midnapore, Birbhum, Murshidabad, Bankura, Hooghly, Nadia, Malda, Purulia \\
\hline Uttar Pradesh & $\begin{array}{l}\text { Allahabad, Azamgarh, Bahraich, Ballia, Barabanki, Bareilly, Basti, Budaon, Deoria, Faizabad, } \\
\text { Ghazipur, Gonda, Gorakhpur, Hardoi, Jaunpur, Kheri, Moradabad, Pilibhit, Pratapgarh, Rampur, Rae } \\
\text { Bareilly, Shahjahanpur, Sitapur, Sultanpur, Unnao }\end{array}$ \\
\hline Andhra Pradesh & $\begin{array}{l}\text { Anantapur, Cuddapah, East Godavari, Guntur, Karimnagar, Khammam, Krishna, Kurnool, Nalgonda, } \\
\text { Nellore, Nizamabad, Warangal, West Godavari }\end{array}$ \\
\hline Bihar & Bhagalpur, Champaran, Gaya, Muzzafarpur, Patna, Purnea, Saharsa, Shanabad \\
\hline Tamil Nadu & Madurai, North Arcot (Vellore), Tanjore, Tiruchirapalli, Tirunelveli, South Arcot (Cuddalore) \\
\hline Orissa & Balangir, Balasore, Cuttack, Dhenkanal, Ganjam, Keonjhar, Kalahandi, Mayurbhanj, Sundargarh \\
\hline Madhya Pradesh & $\begin{array}{l}\text { Balaghat, Chattarpur, Chhindwata, Damoh, Jabalpur, Mandla, Narsimhapur, Panna, Rewa, Sagar, } \\
\text { Satna, Seoni, Sidhi, Tikamgarh }\end{array}$ \\
\hline Karnataka & Bellary, Chikmaglur, Gulbarga, Hassan, Mandya, Mysore, Raichur, Shimoga, Tumkur \\
\hline Punjab & Bhatinda, Firozpur, Jalandhar, Kapurthala, Patiala, Ludhiana, Rupnagar, Sangrur \\
\hline Rajasthan & Pearl Millet (Bajra) \\
\hline Uttar Pradesh & Aligarh, Mainpuri, Farukkhabad, Etawah, Varanasi, Deoria, Pratapgarh \\
\hline Andhra Pradesh & Anantapur, Chittoor,Guntur, Kurnool, Nalgonda, Nellore, Nizamabad, Medak \\
\hline Gujarat & Ahmadabad, Banas Kantha, Bhavnagar, Kheda, Kachch, Mehsana, Rajkot, Sabar Kantha \\
\hline Tamil Nadu & $\begin{array}{l}\text { Madurai, North Arcot (Vellore), Salem, Tiruchirapalli, Tirunelveli, South Arcot (Cuddalore), } \\
\text { Ramanathapuram }\end{array}$ \\
\hline Maharashtra & $\begin{array}{l}\text { Nasik, Dhule, Jalgaon, Ahmadnagar, Pune, Satara, Sangli, Solapur, Aurangabad, Parbhani, Beed, } \\
\text { Osamanabad, Buldhana, Akola, Amravati }\end{array}$ \\
\hline Madhya Pradesh & Gwalior, Guna, Morena, Indore, Jhabua, Rajgarh \\
\hline Karnataka & Bellary, Belgaum, Gulbarga, Bijapur, Raichur, Shimoga, \\
\hline Haryana & Hisar, Mahendragarh, Rohtak \\
\hline
\end{tabular}




\begin{tabular}{|c|l|}
\hline \multicolumn{2}{|c|}{ Sorghum (Jowar) } \\
\hline Rajasthan & Ajmer, Bundi, Jaipur, Jhalawar, Kota, Pali, Tonk, Jodhpur, Nagaur \\
\hline Andhra Pradesh & $\begin{array}{l}\text { Anantapur, Adilabad, Hyderabad, Khammam, Kurnool, Mahbubnagar, Medak, Nalgonda, Nizamabad, } \\
\text { Warangal }\end{array}$ \\
\hline Gujarat & Bharuch, Kachch, Surat, Surendranagar, Vadodara \\
\hline Tamil Nadu & Coimbatore, Madurai, Tiruchirapalli \\
\hline Maharashtra & $\begin{array}{l}\text { Nagpur, Nanded, Jalgaon, Ahmadnagar, Yavatmal,Sangli, Solapur, Aurangabad, Beed, Osamanabad, } \\
\text { Buldhana, Akola, Amravati }\end{array}$ \\
\hline Madhya Pradesh & $\begin{array}{l}\text { Chindwata, Dewas, Dhar, East Nimar, Guna, Mandsaur, Rajgarh, Sehore, Shajapur, Shivpuri, West } \\
\text { Nimar }\end{array}$ \\
\hline Karnataka & Bellary, Belgaum, Gulbarga, Bijapur, Raichur, Mysore, Chitradurga \\
\hline
\end{tabular}


Table A5. Rice with district and year fixed effects

Number of obs $=3464$

R-squared $=0.6422$

Wald chi2 $(41)=5560.04$

Prob $>$ chi $2=0.0000$

\begin{tabular}{|l|r|r|r|r|r|r|}
\hline \multicolumn{1}{|c|}{ Inyield } & \multicolumn{1}{c|}{ Coeff. } & $\begin{array}{c}\text { Panel Corrected } \\
\text { Std. Errors }\end{array}$ & \multicolumn{1}{c|}{$\mathrm{Z}$} & $\mathrm{P}>|\mathrm{z}|$ & \multicolumn{2}{c|}{$95 \%$ Confidence Interval } \\
\hline rainfall & 0.000373 & 0.000124 & 3.02 & 0.003 & 0.000131 & 0.000616 \\
\hline rain $^{2}$ & $-1.02 \mathrm{E}-07$ & $3.38 \mathrm{E}-08$ & -3.02 & 0.003 & $-1.68 \mathrm{E}-07$ & $-3.58 \mathrm{E}-08$ \\
\hline maxtemp & -0.01139 & 0.006877 & -1.66 & 0.098 & -0.02487 & 0.002088 \\
\hline temp $^{2}$ & 0.000145 & 0.000184 & 0.79 & 0.432 & -0.00022 & 0.000506 \\
\hline labour & -0.06606 & 0.089033 & -0.74 & 0.458 & -0.24056 & 0.108441 \\
\hline fertiliser & 0.001309 & 0.000625 & 2.1 & 0.036 & $8.44 \mathrm{E}-05$ & 0.002533 \\
\hline irrigation & 0.374491 & 0.069726 & 5.37 & 0 & 0.237832 & 0.511151 \\
\hline Intercept & -0.63442 & 0.127209 & -4.99 & 0 & -0.88375 & -0.3851 \\
\hline
\end{tabular}

Table A6. Rice with district and year fixed effects, and panel-specific errors

Number of obs $=3464$

R-squared $=0.7910$

Wald chi2 (103) $=972931.02$

Prob $>$ chi $2=0.0000$

\begin{tabular}{|l|r|r|r|r|r|r|}
\hline \multicolumn{1}{|c|}{ Inyield } & \multicolumn{1}{c|}{ Coeff. } & $\begin{array}{c}\text { Panel Corrected } \\
\text { Std. Errors }\end{array}$ & \multicolumn{1}{c|}{$\mathrm{Z}$} & $\mathrm{P}>|\mathrm{z}|$ & \multicolumn{2}{c|}{$95 \%$ Confidence Interval } \\
\hline rainfall & \multicolumn{1}{c|}{0.000334} & 0.000111 & 3.01 & 0.003 & 0.000116 & 0.000552 \\
\hline rain2 & $-8.80 \mathrm{E}-08$ & $2.99 \mathrm{E}-08$ & -2.95 & 0.003 & $-1.47 \mathrm{E}-07$ & $-2.94 \mathrm{E}-08$ \\
\hline maxtemp & -0.00812 & 0.006408 & -1.27 & 0.205 & -0.02068 & 0.004439 \\
\hline temp2 & $7.22 \mathrm{E}-05$ & 0.000179 & 0.4 & 0.687 & -0.00028 & 0.000423 \\
\hline labour & -0.07259 & 0.083447 & -0.87 & 0.384 & -0.23614 & 0.090964 \\
\hline fertilizer & 0.001347 & 0.000581 & 2.32 & 0.02 & 0.000209 & 0.002485 \\
\hline irrigation & 0.350668 & 0.069585 & 5.04 & 0 & 0.214284 & 0.487052 \\
\hline Intercept & -0.57375 & 0.113553 & -5.05 & 0 & -0.79631 & -0.35119 \\
\hline
\end{tabular}




\section{Table A7. Rice with district fixed effects and district-year fixed effects with panel-specific errors}

$$
\begin{array}{ll}
\text { Number of obs } & =\quad 3464 \\
\text {-squared }= & 0.6898 \\
\text { Wald chi2 }(72) & =5.94 \mathrm{e}+11 \\
\text { Prob }>\text { chi2 } & =0.0000
\end{array}
$$

\begin{tabular}{|c|c|c|c|c|c|c|}
\hline lnyield & Coeff. & $\begin{array}{c}\text { Panel } \\
\text { Corrected } \\
\text { Std. } \\
\text { Errors } \\
\end{array}$ & z & $\mathrm{P}>|\mathrm{z}|$ & $95 \%$ Confid & \\
\hline rainfall & 0.082627 & 0.012097 & 6.83 & 0 & 0.058917 & 0.106337 \\
\hline rain2 & -0.0467 & 0.008493 & -5.5 & 0 & -0.06335 & -0.03006 \\
\hline avgtemp & -0.01335 & 0.121461 & -0.11 & 0.912 & -0.25141 & 0.224707 \\
\hline temp2 & 0.061548 & 0.160674 & 0.38 & 0.702 & -0.25337 & 0.376464 \\
\hline irrigation & -0.94739 & 0.373304 & -2.54 & 0.011 & -1.67905 & -0.21573 \\
\hline fertilizer & 0.000506 & 0.000633 & 0.8 & 0.424 & -0.00073 & 0.001747 \\
\hline labour & -0.23855 & 0.117362 & -2.03 & 0.042 & -0.46858 & -0.00852 \\
\hline Intercept & -0.37694 & 0.076133 & -4.95 & 0 & -0.52615 & -0.22772 \\
\hline
\end{tabular}

\begin{tabular}{|l|r|r|r|r|r|r|}
\hline \multicolumn{1}{|c|}{ lnyield } & \multicolumn{1}{c|}{ Coeff. } & $\begin{array}{c}\text { Panel } \\
\text { Corrected } \\
\text { Std. } \\
\text { Errors }\end{array}$ & \multicolumn{1}{c|}{$\mathrm{z}$} & $\mathrm{P}>|\mathrm{z}|$ & \multicolumn{2}{c|}{ 95\% Confidence Interval } \\
\hline rainfall & 0.000565 & 0.00013 & 4.35 & 0 & 0.00031 & 0.000819 \\
\hline rain2 & $-1.38 \mathrm{E}-07$ & $3.49 \mathrm{E}-08$ & -3.95 & 0 & $-2.07 \mathrm{E}-07$ & $-6.97 \mathrm{E}-08$ \\
\hline maxtemp & -0.01933 & 0.005388 & -3.59 & 0 & -0.02989 & -0.00877 \\
\hline temp2 & 0.00028 & 0.00016 & 1.75 & 0.08 & $-3.35 \mathrm{E}-05$ & 0.000593 \\
\hline labour & 0.161255 & 0.079873 & 2.02 & 0.043 & 0.004706 & 0.317804 \\
\hline fertilizer & 0.003364 & 0.000351 & 9.58 & 0 & 0.002676 & 0.004053 \\
\hline irrigation & 0.135486 & 0.063285 & 2.14 & 0.032 & 0.011449 & 0.259522 \\
\hline Intercept & -0.86551 & 0.157207 & -5.51 & 0 & -1.17363 & -0.55739 \\
\hline
\end{tabular}

\section{Table A8. Pearl millet with district and year fixed effects}

$$
\begin{array}{ll}
\text { Number of obs } & =2282 \\
\text { R-squared } & =0.6884 \\
\text { Wald chi2 }(108) & =5840.23 \\
\text { Prob }>\text { chi2 } & =0.0000
\end{array}
$$


Table A9. Sorghum with district and year fixed effects

$\begin{array}{ll}\text { Number of obs } & =1956 \\ \text { R-squared } & =0.7086 \\ \text { Wald chi2(44) } & =91495.10 \\ \text { Prob }>\text { chi2 } & =0.0000\end{array}$

\begin{tabular}{|l|r|r|r|r|r|r|}
\hline \multicolumn{1}{|c|}{ Inyield } & \multicolumn{1}{c|}{ Coeff. } & $\begin{array}{c}\text { Panel } \\
\text { Corrected } \\
\text { Std. Errors }\end{array}$ & \multicolumn{1}{c|}{$\mathrm{z}$} & $\mathrm{P}>|\mathrm{z}|$ & \multicolumn{2}{c|}{$95 \%$ Confidence Interval } \\
\hline rainfall & 0.048642 & 0.022121 & 2.2 & 0.028 & 0.005286 & 0.091999 \\
\hline rain2 & -0.04208 & 0.014794 & -2.84 & 0.004 & -0.07107 & -0.01308 \\
\hline avgtemp & -0.16316 & 0.275169 & -0.59 & 0.553 & -0.70248 & 0.376165 \\
\hline temp2 & 0.426281 & 0.412435 & 1.03 & 0.301 & -0.38208 & 1.234638 \\
\hline labour & -0.36072 & 0.197358 & -1.83 & 0.068 & -0.74753 & 0.026095 \\
\hline fertilizer & $-4.20 \mathrm{E}-05$ & 0.000605 & -0.07 & 0.945 & -0.00123 & 0.001145 \\
\hline irrigation & 0.417307 & 0.324852 & 1.28 & 0.199 & -0.21939 & 1.054005 \\
\hline Intercept & -0.7501 & 0.075956 & -9.88 & 0 & -0.89897 & -0.60123 \\
\hline
\end{tabular}

Table A10. Rice with district and year fixed effects, and regional interactive terms

$\begin{array}{lll}\text { Number of obs } & = & 3464 \\ \text { R-squared } & = & 0.7724 \\ \text { Wald chi2 }(79) & =8.98 \mathrm{e}+08 \\ \text { Prob }>\text { chi2 } & =0.0000\end{array}$

\begin{tabular}{|c|c|c|c|c|c|c|}
\hline lnyield & Coeff. & $\begin{array}{c}\text { Panel } \\
\text { Corrected } \\
\text { Std. Errors }\end{array}$ & $\mathrm{z}$ & $\mathrm{P}>|\mathrm{z}|$ & \multicolumn{2}{|c|}{$95 \%$ Confidence Interval } \\
\hline rainfall & 0.000263 & 0.000152 & 1.73 & 0.083 & $-3.50 \mathrm{E}-05$ & 0.000562 \\
\hline rain2 & $-1.01 \mathrm{E}-07$ & $3.70 \mathrm{E}-08$ & -2.73 & 0.006 & $-1.74 \mathrm{E}-07$ & $-2.86 \mathrm{E}-08$ \\
\hline maxtemp & -0.04796 & 0.08652 & -0.55 & 0.579 & -0.21753 & 0.121619 \\
\hline temp2 & 0.00014 & 0.000184 & 0.76 & 0.448 & -0.00022 & 0.0005 \\
\hline labour & -0.09154 & 0.088802 & -1.03 & 0.303 & -0.26559 & 0.082511 \\
\hline fertilizer & 0.001232 & 0.000549 & 2.24 & 0.025 & 0.000156 & 0.002308 \\
\hline irrigation & 0.385609 & 0.071287 & 5.41 & 0 & 0.245889 & 0.525329 \\
\hline southtemp & 0.036116 & 0.088321 & 0.41 & 0.683 & -0.13699 & 0.209222 \\
\hline northtemp & \multicolumn{6}{|c|}{ (dropped) } \\
\hline eastemp & 0.05291 & 0.100936 & 0.52 & 0.6 & -0.14492 & 0.25074 \\
\hline centraltemp & -0.04998 & 0.083762 & -0.6 & 0.551 & -0.21415 & 0.114185 \\
\hline southrain & \multicolumn{6}{|c|}{ (dropped) } \\
\hline northrain & -0.00004 & 0.000141 & -0.28 & 0.776 & -0.00032 & 0.000236 \\
\hline eastrain & $-1.74 \mathrm{E}-06$ & 0.000134 & -0.01 & 0.99 & -0.00026 & 0.000261 \\
\hline centralrain & 0.000522 & 0.000187 & 2.79 & 0.005 & 0.000155 & 0.000888 \\
\hline Intercept & -0.4641 & 0.141979 & -3.27 & 0.001 & -0.74237 & -0.18583 \\
\hline
\end{tabular}


Table A11. Rice with district and year fixed effects, regional interactive terms, panel-specific errors

Number of obs $=3464$

R-squared $=0.7935$

Wald chi2 (109) $\quad=5.88 \mathrm{e}+06$

Prob $>$ chi $2=0.0000$

\begin{tabular}{|c|c|c|c|c|c|c|}
\hline lnyield & Coeff. & $\begin{array}{c}\text { Panel } \\
\text { Corrected } \\
\text { Std. Errors }\end{array}$ & Z & $\mathrm{P}>|\mathrm{z}|$ & \multicolumn{2}{|c|}{$95 \%$ Confidence Interval } \\
\hline rainfall & 0.000239 & 0.000146 & 1.64 & 0.102 & $-4.70 \mathrm{E}-05$ & 0.000525 \\
\hline rain2 & $-8.35 \mathrm{E}-08$ & $3.46 \mathrm{E}-08$ & -2.41 & 0.016 & $-1.51 \mathrm{E}-07$ & $-1.56 \mathrm{E}-08$ \\
\hline maxtemp & 0.017899 & 0.05927 & 0.3 & 0.763 & -0.09827 & 0.134066 \\
\hline temp2 & $6.88 \mathrm{E}-05$ & $1.82 \mathrm{E}-04$ & 0.38 & 0.705 & $-2.87 \mathrm{E}-04$ & $4.25 \mathrm{E}-04$ \\
\hline labour & -0.11647 & 0.084019 & -1.39 & 0.166 & -0.28114 & 0.048206 \\
\hline fertilizer & 0.001273 & 0.000503 & 2.53 & 0.011 & 0.000286 & 0.002259 \\
\hline irrigation & 0.395948 & 0.072279 & 5.48 & 0 & 0.254284 & 0.537612 \\
\hline southtemp & -0.02661 & 0.058402 & -0.46 & 0.649 & -0.14108 & 0.087856 \\
\hline northtemp & -0.0651 & 0.090262 & -0.72 & 0.471 & -0.24201 & 0.111811 \\
\hline eastemp & \multicolumn{6}{|c|}{ (dropped) } \\
\hline centraltemp & -0.09878 & 0.075487 & -1.31 & 0.191 & -0.24674 & 0.049168 \\
\hline southrain & \multicolumn{6}{|c|}{ (dropped) } \\
\hline northrain & $-2.66 \mathrm{E}-05$ & 0.000127 & -0.21 & 0.835 & -0.00028 & 0.000223 \\
\hline eastrain & $-3.00 \mathrm{E}-05$ & 0.000126 & -0.24 & 0.811 & -0.00028 & 0.000218 \\
\hline centralrain & 0.000453 & 0.000176 & 2.57 & 0.01 & 0.000108 & 0.000798 \\
\hline Intercept & -0.39766 & 0.131838 & -3.02 & 0.003 & -0.65605 & -0.13926 \\
\hline
\end{tabular}


Table A12. Pearl millet with district and year fixed effects and regional interactive terms

Number of obs 2282

R-squared 0.6949

Wald chi2 (112) 6100.94

Prob > chi2 0.0000

\begin{tabular}{|c|c|c|c|c|c|c|}
\hline lnyield & Coeff. & $\begin{array}{c}\text { Panel } \\
\text { Corrected } \\
\text { Std. Errors } \\
\end{array}$ & $\mathrm{Z}$ & $\mathrm{P}>|\mathrm{z}|$ & \multicolumn{2}{|c|}{$95 \%$ Confidence Interval } \\
\hline rainfall & 0.032135 & 0.01551 & 2.07 & 0.038 & 0.001736 & 0.062534 \\
\hline rain2 & -0.04807 & 0.008497 & -5.66 & 0 & -0.06472 & -0.03141 \\
\hline avgtemp & -1.55039 & 0.465034 & -3.33 & 0.001 & -2.46184 & -0.63894 \\
\hline temp2 & -0.13495 & 0.160873 & -0.84 & 0.402 & -0.45025 & 0.180359 \\
\hline irrigation & -0.54575 & 0.381318 & -1.43 & 0.152 & -1.29312 & 0.201625 \\
\hline fertilizer & 0.000678 & 0.000627 & 1.08 & 0.279 & -0.00055 & 0.001907 \\
\hline labour & -0.3416 & 0.118153 & -2.89 & 0.004 & -0.57318 & -0.11002 \\
\hline northrain & 0.089207 & 0.032144 & 2.78 & 0.006 & 0.026206 & 0.152208 \\
\hline centralrain & 0.030679 & 0.021514 & 1.43 & 0.154 & -0.01149 & 0.072845 \\
\hline southrain & & & & (dropped) & & \\
\hline northtemp & & & & (dropped) & & \\
\hline southtemp & 1.702453 & 0.464222 & 3.67 & 0 & 0.792595 & 2.61231 \\
\hline centraltemp & 1.617029 & 0.463409 & 3.49 & 0 & 0.708764 & 2.525295 \\
\hline Intercept & -0.3484 & 0.076683 & -4.54 & 0 & -0.49869 & -0.1981 \\
\hline
\end{tabular}

Table A13. Sorghum with district and year fixed effects and regional interactive terms

Number of obs 1956

Wald chi2(48) 93250.33
R-squared 0.7195

Prob > chi2 0.0000

\begin{tabular}{|l|r|r|r|r|r|r|}
\hline \multicolumn{1}{|c|}{ Inyield } & \multicolumn{1}{c|}{ Coeff. } & $\begin{array}{c}\text { Panel } \\
\text { Corrected } \\
\text { Std. Errors }\end{array}$ & \multicolumn{1}{c|}{$\mathrm{Z}$} & \multicolumn{2}{c|}{$\mathrm{P}>|\mathrm{z}|$} & \multicolumn{2}{c|}{$95 \%$ Confidence Interval } \\
\hline rainfall & 0.240363 & 0.087184 & 2.76 & 0.006 & 0.069487 & 0.41124 \\
\hline rain2 & -0.04789 & 0.014226 & -3.37 & 0.001 & -0.07578 & -0.02001 \\
\hline avgtemp & -0.74816 & 0.977292 & -0.77 & 0.444 & -2.66361 & 1.167302 \\
\hline temp2 & 0.1707 & 0.390867 & 0.44 & 0.662 & -0.59539 & 0.936785 \\
\hline labour & -0.41868 & 0.193439 & -2.16 & 0.03 & -0.79782 & -0.03955 \\
\hline fertilizer & $-8.20 \mathrm{E}-05$ & 0.000603 & -0.14 & 0.892 & -0.00126 & 0.0011 \\
\hline irrigation & 0.474989 & 0.329623 & 1.44 & 0.15 & -0.17106 & 1.121037 \\
\hline northrain & & \multicolumn{7}{|c|}{ (dropped) } & -0.04222 \\
\hline centralrain & -0.21331 & 0.087294 & -2.44 & 0.015 & -0.38441 & -0.06161 \\
\hline southrain & -0.2374 & 0.089689 & -2.65 & 0.008 & -0.41319 & \\
\hline northtemp & & & \multicolumn{7}{|c|}{ (dropped) } & \\
\hline southtemp & 0.741189 & 0.980375 & 0.76 & 0.45 & -1.18031 & 2.662689 \\
\hline centraltemp & 0.759614 & 0.969976 & 0.78 & 0.434 & -1.1415 & 2.660732 \\
\hline Intercept & -0.74737 & 0.075717 & -9.87 & 0 & -0.89578 & -0.59897 \\
\hline
\end{tabular}


Table A 14. Predicted changes in yield: short-run climate change scenario (2010-2039)

\begin{tabular}{|c|c|c|}
\hline Crop & Regions & Percentage change in yield \\
\hline Rice & Wettest & -1.21 \\
\hline & Wet & 0.88 \\
\hline & Dry & 0.74 \\
\hline Pearl Millet & Driest & -0.91 \\
\hline & Wettest & 1.15 \\
\hline & Dry & 1.13 \\
\hline & Driest & 0.63 \\
\hline Sorghum & Wettest & 0.71 \\
\hline & Wet & -0.55 \\
\hline & Dry & -0.93 \\
\hline & Driest & -1.02 \\
\hline
\end{tabular}

Note:

- For each crop, all districts have been divided into four buckets, on the basis of the amount of rainfall received over the period 1966-1999.

- The predicted changes in climate change used for the calculations are a $0.5^{\circ} \mathrm{C}$ rise in temperature, and 4\% increase in precipitation in the short-run (2010-2039) over the base period (1961-1990) (IPCC Emissions Scenarios 2007)

- The model equations used to calculate the predicted change in yield are given by tables 1,2 and 3 in the Results section

- The (percentage) final change in yield is given by:

$\mathrm{Y}=$ yield

$$
\Delta \mathrm{Y}=[(\partial \mathrm{Y} / \partial \mathrm{R}) * \Delta \mathrm{R}+(\partial \mathrm{Y} / \partial \mathrm{T}) * \Delta \mathrm{T}] * 100, \text { where }
$$

$\mathrm{R}=$ rainfall

$\mathrm{T}=$ temperature

and $(\partial \mathrm{Y} / \partial \mathrm{R})$ and $(\partial \mathrm{Y} / \partial \mathrm{T})$ are determined by the model equations 